\title{
KEPEMIPINAN DALAM POLITIK YANG \\ DI INGINKAN MASYAKAT BANJAR
}

\author{
Yusup \\ Email : 2010128210007@mhs.ulm.ac.id
}

Program Studi Pendidikan IPS Fakultas Keguruan dan Ilmu Pendidikan

Universitas Lambung Mangkurat

Banjarmasin

\begin{abstract}
Dunia memiliki Nagara-Negara yang memiliki Pemimpin yang berkualitas sangat baik dalam kepemimpinannya sebab setiap pemimpin memiliki kerisma,wibawa dan sebagainya yang menjadi suatu pemimpin yang diinginkan setiap orang dalam memberikan komando yang sangat baik dalam menjalankan kewajiabannya terhadap amanah yang diberikan saat pemilihan pemimpin. Salah satu ialah Negara Indonesia yang memiliki banyaknya provinsi salah satunya Provinsi Kalimantan Selatan yang memiliki Tokoh yakni Pangeran Antasari yang menjadi suatu Pemimpin sangat baik terhadap masyarakatnya. Maka dengan mengenal Pemimpin berkualitas menjadi sebuah pembelajaran politik bagi daerah banjar karena sudah mengenal pemimpin yang berkualitas dari perananan, pendekatan dan persyaratannya menjadi pemimpin.
\end{abstract}

\section{PENDAHULUAN}

Suatu Negara di Dunia pastinya memiliki suatu Pemimpin entah itu sebagai pemerintahan maupun tidak pemerintahan. Salah satunya ialah Negara Indonesia. Negara Indonesia memiliki Pemimpin yang sangat berkesan, berkrisma, berwiba dan sebagainya yang terkenal hingga penjuru dunia. Dan Negara Indonesia sendiri memiliki suatu wilayah dari sabang sampai merauke dengan sangat banyaknya pulau serta memiliki wilayahnya masingmasing yang pastinya memiliki pemimpinan di wilayah tersebut agar dapat menjalankan serta bisa menjadi suatu acuan yang sangat baik bagi menjalankan suatu negara yang baik dengan kekuasaan dari pemimpin tersebut terhadap masyarakat yang ada.

Kalimantan selatan meruapakan salah satu provinsi dari Negara Indonesia yang memiliki wilayah yakni Banjarmasin, Banjarbaru dan sebagainya. Kalimatan selatan terletak di pulau kalimatan dan memiliki ibu kota di kota banjarmasin. Kalimantan selatan memiliki berbagai etnis atau suku bangsa yang sangat banyak, salah satunya ialah suku banjar yang mana suku banjar yang sangat ramah dan sangat baik dalam bermasyarakat. 
Ilmu Politik ialah suatu ilmu yang sangat penting dalam kehiduapan sebab adanya sautu pembelajaran yakni berkenanan dengan pemerintahan, kekuasaan, kewenangan dan sebagainya sehhinga dapat menyelesaikan permasalhan yang ada di kehiduapan diri,bangsa dan negara. Politik ialah adanya pemerintah dari suatu negara yang terorganisir yang menekankan pada ke lembagaan kepemimpinan serta pengalokasikan suatu nilai secara otoritatif yang adanya kewenangan yang diakui oleh seluruh masyarakat sebab politik pada dasarnya ialah suatu fenomena yang sangat erat kaitanya dengan aktivitas manusia yang hidup bermasyakat dalam menghasilakan suatu diri manusia dalam proses perkembangan menuju suatu yang di inginkan sesuai dengan ketentuan.

Kepemimpinan ialah adanya suatu usaha sesorang dalam memberikan bimbingan dalam mencapai suatu tujuan serta adanya intraksi yang saling mempengaruhi terhadap sesorang walaupun sering kali tidak sesuai dengan keinginan agar dapat menjadikan suatu sistem kekuasaan dalam suatu masyarakat berjalan dengan sangat baik sesuai dengan ketentuan dan ketetapan yang sudah di tetapkan.

\section{METODE PENELITIAN}

Metode yang digunakan pada artikel ini ialah dengan adanya pendekatan deskriftif kualitatif yang mana cara yang di pergunakan dalam pengumpulan data mengunakan studi literasi berupa pengumpulan berbagai sumber bacaan seperti artikel, jurnal dan buku terkait mengenai kepemimpinan dalam politik yang diinginkan orang banjar dan pembelajaran politik dari kepemimpinan yang menghasilkan suatu artikel.

\section{PEMBAHASAN}

\section{KEPEMIPINAN}

Kepemimpinan ialah adanya suatu hubungan yang mengaruhi seseorang dan sekelompok dalam aktivitas nya dalam mengarahkan serta membimbing untuk mencapi tujuan bersama walaupun sering terjadi tidak sesuai dengan kenyataannya dari suatu keputusan yang akan di ambil akan tetapi suatu keputusan yang akan diambil bisa di lakukan dengan adanya intraksi kepada yang lain yang nantinya dapat menjadi suatu keputusan bersama yakni dari 
hasil musyawarah dalam perpolitikan yang terjadi setiap waktu dan di setiap tempat yakni salah satunya di perpolitikan masyarakat banjar.

Masyarakat banjar sendiri ialah orang yang sangat baik dan selalu memenuhi kewajibanannya terhadap perpolitikan yang ada akan tetapi sering kali terjadinya konflik yang disebab kan karena adanya suatu kepemimpinan yang tidak dinginkan masyarakat ketika sudah terpilih menjadi pemimpin mereka yang mana akibatnya sering kali terjadi penyeruan masyakat yang berkomentar dalam suatu proses dalam menjalankan kepemimpinan yang di lakukan secara langsung dan tidak langsung yang dapat di lihat dari salah satunya ialah sosial media entah komentarnya memberikan suatu saran dan ada pula menjadikan suatu hal yang tidak di inginkan terjadi yang menjadikan suatu konflik.

Peranan Dunia Pendidikan terhadap masyakat banjar yakni menjadikan anak mereka menjadi lebih terbimbing dalam pengetahuan serta berperilaku yang baik yang berkenan perpolitikan agar menghindarkan dari hal hal yang tidak diinginkan yang merugikan diri sendiri dan orang lain misalnya adanya Demo secara besar-besaran mengenai suatu keputusan atau kebijakan yang akan diterapkan tetapi sangat tidak sesuai oleh pemimpinnya terhadap masyarakat. Maka dari itu adanya pendidikan politik yang meruapakan suatu upaya untuk menjadikan atau membentuk setiap individu yang berkualitas dalam memahami perpolitikan.

Maka dapat menjadi pembelajaran bagi masyarakat dalam memilih Pemimpin yang berkualitas yakni ahli di bidangnya serta memiliki kejujuran, bertanggung jawab serta siap membuka ruang diskusi ketika adanya suatu kebijakan serta keputusan yang tidak sesuai agar masyarakat menjadi suatu penurunan dalam penilaian masyarakat terhadap pemimpinnya sebab dengan penurunan maka para pemimpin yang berkualitas bisa menjalankan tugasnya dari segara urusan dan tindakan mengenai pemerintahan akibatnya terciptalah pemimpin dan masyarakat damai dan sejahtera.

Salah satu Tokoh Kalimantan selatan ialah Pangeran Antasari. Pengeran Antasari menjadi sosok raja yang memiliki keagamaan yang sangat baik yang menjadi nilai dasar moral dalam memimpin masyakarat sebab memiliki slogan yakni "Haram menyerah, waja sampai keputing" bagi Pangeran Antasari yang tidak mau melanggar serta mengkhianati amanah yang diberikan masyarakat kepadanya dalam bersikap, berbuat serta bertindak sesuai ketentuan yang ada di ajaran agama. 


\section{Peranan Kepemimpinan}

Sebagai Pemimpin pastinya memiliki tanggung jawab sangat besar maka harus mengetahui perannya agar dapat menjadi sosok pemimpin yang di inginkan. Menurut Soliha, E., \& Hersugondo, H. (2008) Peranan Pemimpin sebagai berikut ;

Peranan Kepemimpinan dalam Hubungan Pribadi ( Interpersonal Role )

- Peran Sebagai Tokoh.

Pemimpinan yang berperan sebagai Tokoh ialah selalu ada untuk mewakili suatu kelompok atau organisasi yang dipimpinya dalam aktivitas atau sauatu acara resmi maupun non resmi. Misalnya menghadiri suatu upacara resmi dalam rangka mewakili kelompok atau oranganisasi di pimpinya serta tidak memihak kepada golongan atas tetapi menyamaratakan agar tidak adanya kesepihakan dan dalam pengambilann kebijakan dengan musyawarah dalam kejujuran.

- Peran Sebagai Pemimpin ( Leader Role )

Pemimpinan yang berperan sebagai pemimpin ialah adanya pemimpin yang mampu dalam menjalankan suatu fungsi yang mendasar yakni memimpin, mengendalikan, serta mengembangkan yang mana hasilnya akan menjadi suatu lebih baik sebab pemimpinnya aktif dalam segala hal yang akan dijalankannya.

- Peran Sebagai Penghubung ( Liaison Role )

Pemimpin yang berperan sebagai penghubung ialah adanya peran pemimpin dalam melakukan interaksi dengan sekitar untuk mendapatkan informasi dan data yang sangat penting bagi pemimpin tau apa yang terjadi dari masih banyaknya masalah dan bagaimana untuk menjadikan suatu penyelesaian terhadap apa yang terjadi serta menjadikan informasi tersebut dalam meningkatkan suatu kepemimpinan yang sangat berkualiatas baik agar semua tujuan dapat terwujud.

Jadi Pemimpin setidaknya memiliki 3 peranan ini yakni sebagai Tokoh, Pemimpin dan Penghubung sebab masyarakat sangat menginginkan ini yang ada pada para pemimpin mereka oleh sebab itu maka perlu lah para pemimpin itu mengetahui perannya dalam menjalankan yang sudah diberikan amanah yang sangat besar dalam menjaga serta menjadi kedamaian bersama-sama. 
Pendekatan Kepemimpinan

Kepemimpinan juga perlu memiliki pendekatan yang baik ketika mereka jadi pemimpin. Yang di kemukakan oleh Yukl (1989) Kepemimpinan memiliki 3 macam pendekatan. Sebagai berikut ;

1. Pendekatan Pengaruh Kekuasaan.

Adanya level mikro kekuasaan setiap individual dengan level makro kekuasaan pada sub unit dan koalisi organisasi maka dari sebab itu Kepemimpinan harus efektif yang pastiya akan sering di evaluasi dalam beradaptasi dengan suatu perubahan sekitar akibat waktu yang terus berjalan dengan adanya kebutuhan yang harus ubah menjadi lebih mudah. Maka dari itu sejumlah posisi kekuasaan untuk Kepemimpinan yang efektif perlu memiliki ialah ada 5 basis kekuasaaan. Sebagai berikut ;

a. Kekuasaan Legitimasi ialah adanya kemampuan indivdiu dalam mempengaruhi sesorang karena kekuasannya atau posisi/jabatannya.

b. Kekuasaan Imbalan ialah kekuasaan yang didasari pada suatu kemampuan individu untuk memberi sesuatu kepada orang lain sebagai imbalan karena ketaatan mereka.

c. Kekuasaan Paksaan ialah kekuasaan adanya suatu hukuman yang mana hukum sendiri sebagai konsekuensi dari suatu tindakan yang di rasakaan dari ketidak nyamanannya pada setiap orang yang menerimannya agar mengubah perilaku yang telah melakukan perilaku tidak baik dan mengubahnya kepada lebih bermanfaat.

d. Kekuasaan Ahli ialah kekuasaan yang dimilik individu ketika ia sangat ahli di bidangnya dengan khusus dan memiliki nilai yang tinggi.

e. Kekuasaan Panutan ialah kekuasan individu yang menyatakan bahwa diri diperngaruhi oleh seseorang sebab adanya gaya kepribadian atau prilaku orang bersangkutan sangat baik yang sering disebut karisma.

\section{Pendekatan Prilaku}

Pendekatan Perilaku ialah adanya suatu penekanan terhadap pemimpin secara nyata berkerja dalam perkerjaan dan intraksi keefektifannya karena adanya hubungan perencanaan dan egektifan yang dalam perencaann yang efektif sering tidak formal dan fleksibel di bandingkan formal dan kaku. 


\section{Pendekatan Sifat.}

Pendekatan sifat ialah adanya suatu penekanan pada pemakaian personal bagi sosok pemimpin sebab ada hubungan pdengan syarat-syarat persan yang spesifik pada setiap pperbedaan posisi/ jabatan akibatnya adanya pemimpin yang efektif yang memiliki kekuasaan kuat, berprestasi banyak, serta afiliasi lebuh lemah.

\section{Pendekatan Situasional.}

Pendekatan situasional ialah adanya penekanan pada faktor, kontekstual yakni otoritas, kebijakasaann pemimpin, perkerjaan yang memiliki sifat alami oleh unit ppemimpin dan memiliki lingkungan eksternal.

Jadi Sesorang Pemimpin akan memiliki 4 pendekatan ini yakni pengaruh kekuasaan, perilaku, sifat dan situasional dalam menjalankan kepemimpianannya sesuai dengan keinginan masyarakat banjar sebab dengan adanya pendekatan tersebut menjadi suatu bentuk yang nanti menghasilkan suatu hubungan baik sendiri pemimpin dan masyakarakatnya.

Persyaratan Kepemimpin

Suatu Pemimpin pastinya memiliki persyarat syaratan kepemimpinan sebab pemimpin nantinya menjadi sosok sesorang yang sangat penting dalam suatu lembaga dan dikalangan masyarakat sehingga di haruskan memiliki persyaratnnya tertentu dan memiliki suatu kelebihan daripada orang yang nanti dipimpinnya. Jadi Persyaratan yang harus dimiliki oleh sosok Pemimpin, Sebagai berikut ;

\section{1) Agama Kuat}

Seseorang Pemimpin yang memiliki Agama kuat maka dimana ku dan dalam keadaan apapun dalam kepemimpinannya insya allah amanah sebab adanya rasa suatu keyakinan kuat dalam berperilaku dan bertindak akibatnya dalam kepemimpiannya sesuai dengan ketentuan yang menjadi tanggung jawabnnya.

\section{2) Mental Kuat}

Seseorang pemimpin yang memiliki mental kuat maka dalam menghadapi suatu permasalahan akan selalu dapat terselesaikan sebab adanya mental kuat yang menjadikan pemimpin ketika ada permasalahan bisa berpikir dengan baik bagaimana dalam 
menyelesaikanya yakni salah satunya ialah dengan musyawarah bersama agar tidak adanya pihak pihak yang dirugikan dan menghasilkan suatu keputusan yang baik.

\section{3) Kekuasaan}

Seseorang pemimpin yang memiliki suatu kekuasaan pastinya menjadi nilai tambah ketika ia terpilih nantinya menjadi pemimpin karena adanya kekuasaan yang mana di tempat kekuasaannya sudah memiliki pandangann baik dari masyarakat kepada mya maka dalam kepemimpinan tidak ada masalah.

\section{4) Karisma}

Sesorang pemimpin yang memiliki suatu kewibaan pastinya memiliki suatu kelebihan pada dirinya yang entah itu segi keungulan pengetahuan yakni keilmuan, kemampuan hingga menjadi sautu keahlian khusus yang sangat baik menjadi suatu pemimpin yang berkualitas.

\section{5) Kecakepan/ kemampuan}

Seseorang pemimpin yang memiliki kecakepaan/kemampuan dalam katerampilannya dalam segala hal yakni adanya suatu keahlian yang dimilikinya. Sebab sorang pemimpin pasti tidak luput dari ketidak sempurnaan yang menjadikan nanti adanya permasalahan akan tetapi bisa tertutupi dengan adnaya kelebihan yakni memiliki pengetahuan luas, kreatif, percaya diri, sopan ramah, rendah hati, jujur, amanah, bertangung jawab dan sebagainya.

Jadi persyaratan kepemimpinan ini sangat penting agar menjadi pemimpin yang berkualitas dan sesuai dengan keinginan masyarakat banjar yang nantinya menjadi sosok yanng sangat mempengaruhi terhadap masyarakatnya sebab dengan adanya 5 persyaratan tersebut sudah ada pada diri pemimpin maka insya allah dalam menjalankan kepemimpiannya akan lancar.

\section{SIMPULAN}

Kepemimpinan ialah adanya suatu upaya sesorang dalam memberikan arahan dan bimbingan dalam mencapai suatu tujuan dalam berhubugan yang saling mempengaruhi terhadap orang lain walaupun ada saja saat tidak sesuainya dengan keinginan akan tetapi dengan adanya pemimpin yang berkualitas baik dalam menjalankan tugas dan bertanggung 
jawab penuh dalam kepemimpinannya itu sangat lah di inginkan masyarakat karena sesuai dengan ketentuan dan ketetapan yang baik.

Jadi Pemimpin setidaknya memiliki 3 peranan ini yakni sebagai Tokoh, Pemimpin dan Penghubung sebab masyarakat sangat menginginkan ini yang ada pada para pemimpin mereka oleh sebab itu maka perlu lah para pemimpin itu mengetahui perannya dalam menjalankan yang sudah diberikan amanah yang sangat besar dalam menjaga serta menjadi kedamaian bersama-sama.

Sesorang Pemimpin akan memiliki 4 pendekatan ini yakni pengaruh kekuasaan, perilaku, sifat dan situasional dalam menjalankan kepemimpianannya sesuai dengan keinginan masyarakat banjar sebab dengan adanya pendekatan tersebut menjadi suatu bentuk yang nanti menghasilkan suatu hubungan baik sendiri pemimpin dan masyakarakatnya

Persyaratan kepemimpinan ini sangat penting agar menjadi pemimpin yang berkualitas dan sesuai dengan keinginan masyarakat banjar yang nantinya menjadi sosok yanng sangat mempengaruhi terhadap masyarakatnya sebab dengan adanya 5 persyaratan tersebut sudah ada pada diri pemimpin maka insya allah dalam menjalankan kepemimpiannya akan lancar.

Jadi Kepemimpinan akan menjadi suatu pembelajaran politik bagi masyarakat daerah banjar sebab dengan mengetahui pemimpin yang berkulitas maka dalam pemilihannya nanti akan lebih baik dalam menentukan pemimpin yang baik ketika sudah mengetahui diri pasangan calon yang menjadi pemimpin bagi masyarakat daerah banjar sendiri dan terhindar dari berbagai masalah yang seharusnya tidak terjadi bisa tidak ada karena sosok kepemimpinan sangat berkualitas.

\section{REFERENSI}

Affandi, I., \& Suryadi, K. (2010). Teori dan Konsep dalam Konteks Pendidikan Politik.

Anis, M. Z. A. (2015). Sejarah Bukan Warisan Melainkan Pembelajaran.

Anis, M. Z. A., Sriwati, S., \& Mardiani, F. SISI ABU-ABU KAUSALITAS DAN EVALUASINYA DALAM PEMBELAJARAN SEJARAH. Jurnal Socius, 9(2), 169180.

Anis, M. Z. A. (2013). ILMU SEJARAH SEBAGAI SUMBER PEMBELAJARAN IPS. Mewacanakan Pendidikan IPS, 149. 
Arifin, Z., \& Rohmah, L. (2019). THE CONCEPT OF LEADERSHIP OF THE TRANSNATIONAL ISLAMIC IDEOLOGY PERSPECTIVE AND RESPONSES TO DEMOCRACY PRACTICES IN INDONESIA. AKADEMIKA: Jurnal Pemikiran Islam, 24(1), 213-232.

Hamdiah, H. (2021). PERILAKU KEPEMIMPINAN DALAM PANDANGAN ISLAM. Proceeding: Islamic University of Kalimantan.

Maulana, M. R. (2020). Peran Kepemimpinan Dalam Meningkatkan Kinerja Pegawai Di Kantor Badan Kesatuan Bangsa dan Politik Kota Banjarmasin (Doctoral dissertation, Universitas Islam Kalimantan MAB).

Mirhan, A. M. (2017). Agama dan Politik di Kalimantan Selatan. Jurnal Ilmiah Ilmu Ushuluddin, 15(2), 111-121.

Nambo, A. B., \& Puluhuluwa, M. R. (2005). Memahami tentang beberapa konsep politik (suatu telaah dari sistem politik). MIMBAR: Jurnal Sosial Dan Pembangunan, 21(2), 262-285.

Purwanto, N. A. (2008). Pengaruh Politik Dalam Bidang Pendidikan. Jurnal Manajemen Pendidikan UNY, 114488.

Rachmawati, A. L., \& Ratnawati, S. (2020). HARMONISASI PROSES PEMBELAJARAN MELALUI TEORI KEPEMIMPINAN BERBASIS ASAH ASIH ASUH. Soedirman Economics Education Journal, 2(2), 34-45.

Subiyakto, B., Abbas, E. W., Arisanty, D., Mutiani, M., \& Akmal, H. (2020). Sungai dan Kehidupan Masyarakat Banjar: Penguatan Lokalitas dalam Wacana Pendidikan IPS yang Responsif.

Soliha, E., \& Hersugondo, H. (2008). Kepemimpinan Yang Efektif Dan Perubahan Organisasi. Fokus Ekonomi, 7(2), 24400.

Winarno, B. (2018). Ilmu Sosiol dan Ilmu Politik: Filsafat, Teori dan Metodologi. Paradigma, $17(1)$.

Yunas, N. S. (2016). Membangun Karakter Kepemimpinan dan Optimisme Daerah dalam Reformasi Birokrasi di Indonesia. The POLITICS: Jurnal Magister Ilmu Politik Universitas Hasanuddin, 290-314. 